\title{
The genus Ruppia L. (Ruppiaceae) in the Mediterranean region: An overview
}

\author{
Anna M. Mannino ${ }^{a, *}$, M. Menéndez ${ }^{b}$, B. Obrador ${ }^{b}$, A. Sfriso ${ }^{c}$, L. Triest $^{d}$ \\ a Department of Sciences and Biological Chemical and Pharmaceutical Technologies, Section of Botany and Plant Ecology, University of Palermo, Via \\ Archirafi 38, 90123 Palermo, Italy \\ ${ }^{\mathrm{b}}$ Department of Ecology, University of Barcelona, Av. Diagonal 643, 08028 Barcelona, Spain \\ ' Department of Environmental Sciences, Informatics \&' Statistics, University Ca' Foscari of Venice, Calle Larga S. Marta, 2137 Venice, Italy \\ ${ }^{\mathrm{d}}$ Research Group 'Plant Biology and Nature Management', Vrije Universiteit Brussel, Pleinlaan 2, B-1050 Brussels, Belgium
}

\section{A R T I C L E I N F O}

\section{Article history:}

Received 23 December 2013

Received in revised form 17 February 2015

Accepted 19 February 2015

Available online 26 February 2015

\section{Keywords:}

Aquatic angiosperms

Ruppia

Shallow waters

Mediterranean region

Overview

\begin{abstract}
A B S T R A C T
This paper reviews the current knowledge on the diversity, distribution and ecology of the genus Ruppia L. in the Mediterranean region. The genus Ruppia, a cosmopolitan aquatic plant complex, is generally restricted to shallow waters such as coastal lagoons and brackish habitats characterized by fine sediments and high salinity fluctuations. In these habitats Ruppia meadows play an important structural and functional role. Molecular analyses revealed the presence of 16 haplotypes in the Mediterranean region, one corresponding to Ruppia maritima L., and the others to various morphological forms of Ruppia cirrhosa (Petagna) Grande, all together referred to as the "R. cirrhosa s.l. complex", which also includes Ruppia drepanensis Tineo. Populations of hybrid origin between $R$. maritima and $R$. cirrhosa and polyploidy have been detected.
\end{abstract}

(C) 2015 Elsevier B.V. All rights reserved.

\section{Introduction}

The cosmopolitan genus Ruppia L. (Ruppiaceae) inhabits a wide variety of shallow systems (coastal lagoons, continental brackish habitats or saltmarsh ponds), where it forms dense and often monospecific meadows that play a key role in the functioning of the ecosystem (Verhoeven, 1979; Calado and Duarte, 2000; Teixeira da Silva and Asmus, 2001; Menéndez, 2002; Malea et al., 2004; Den Hartog and Kuo 2006; Mannino and Sarà, 2006; Pergent et al., 2006; Rodrigues et al., 2009; Obrador and Pretus, 2012). Ruppia species are characterized by a simplified morphology that often shows high phenotypic plasticity, leading to taxonomic confusion (Van Vierssen et al., 1981; Hara, 1983; Aedo and Fernández Casado, 1988; Ito et al., 2010). Although the ecology, biomass, productivity and ecophysiology of Ruppia species have been widely investigated, the ecotypic and genotypic variation at population level remains only partly understood (Triest and Symoens, 1991; Green and Short, 2003; Den Hartog and Kuo 2006; Triest and Sierens, 2013, 2014).

At present, three species are recognized in the Mediterranean region, $R$. maritima L., $R$. cirrhosa (Petagna) Grande and $R$. drepanensis Tineo (considered by Zhao and Wu, 2008 as synonym of $R$.

\footnotetext{
* Corresponding author. Tel.: +39 91 23891218; fax: +39 916165997.

E-mail address: annamaria.mannino@unipa.it (A.M. Mannino).
}

cirrhosa), the latter occurring only in the south-western Mediterranean (Comín et al., 1993; Triest and Sierens, 2009a, 2013, 2014; Ito et al., 2013). Recently, hybrid populations between $R$. maritima and $R$. cirrhosa have been detected (Ito et al., 2013; Triest and Sierens, 2013, 2014).

Ruppia taxonomy has been confusing because of the simplified morphology, high phenotypic plasticity, as well as the existence of polyploidy and hybrids that make it difficult to name Ruppia species and have a reliable map of their distribution. The present overview, based on studies conducted during the last 40 years, aims at: a) understanding Ruppia diversity and mapping its distribution in the Mediterranean basin on the basis of recent molecular studies, b) critically compiling the taxonomic status of Mediterranean Ruppia, c) highlighting the main factors affecting Ruppia growth, distribution and production, and d) making a comparison with Ruppia habitats of other regions in the world.

\section{The genus Ruppia}

\subsection{Taxonomy}

On the basis of morphological features, the genus Ruppia has been traditionally included either within the monogeneric family of Ruppiaceae (Cronquist, 1981; Tomlinson, 1982; Les et al., 1997) or within the family of Potamogetonaceae (Gamerro, 1968; Jacobs 
and Brock, 1982; Dahlgren et al., 1985). Molecular analyses have highlighted a close phylogenetic relationship of Ruppiaceae with seagrass families such as Cymodoceaceae and Posidoniaceae (Les et al., 1997; Zhao and Wu, 2008; Triest and Sierens, 2014).

The high phenotypic plasticity that characterizes this genus has often led to taxonomic confusion (Van Vierssen et al., 1981; Hara, 1983; Aedo and Fernández Casado, 1988; Ito et al., 2010). Disagreement among specialists on the number of Ruppia taxa, has led to the proposition of a high number of species, most of which are probably morphotypes of R. maritima (Setchell, 1946; Richardson, 1980; Den Hartog, 1981; Kantrud, 1991; Zhao and Wu, 2008), a species with a nearly cosmopolitan distribution (De Oliveira et al., 1983; Orth and Moore, 1988; Malea et al., 2004; Short et al., 2007). Moreover, the occurrence of morphological intermediates with sterile flowers in local populations, suggests that intragenus hybridization may have occurred, making identification even more complicated (Ito et al., 2010).

At present, several species are recognized worldwide: $R$. cirrhosa, R. maritima, R. megacarpa Mason, R. tuberosa Davis \& Tomlinson, $R$. polycarpa Mason (Brock, 1982a,b; Zhao and Wu, 2008). R. maritima and $R$. cirrhosa are the most widely distributed species, whereas the other three are regarded as endemic to Oceania.

With reference to European habitats, some authors reported only one species, R. maritima (Ascherson and Graebner, 1907; Tallon, 1957; Van Ooststroom and Reichgelt, 1964), whereas others recognized two species: $R$. cirrhosa and R. maritima (Roze, 1904; Hagström, 1911; Reese, 1962; Den Hartog, 1971; Sfriso, 2010). In the Mediterranean region, three species have been found: $R$. maritima, $R$. cirrhosa and $R$. drepanensis, the latter recognized as an inland ecotype of the SW Mediterranean or a variety, $R$. cirrhosa var. drepanensis (Tineo) Symoens (Van Vierssen et al., 1981; Cirujano, 1986; Aedo and Fernández Casado, 1988; Cirujano and García-Murillo, 1990; Triest and Symoens, 1991; Comín et al., 1993; Talavera et al., 1993; Triest and Sierens, 2009a,b, 2010, 2013, 2014). The morpho-anatomy of Ruppia species as well as the main morphological characteristics of Mediterranean species are reported in Appendix 1 and Table S1, respectively (see also Figs. 1 and 2). An identification key for the Ruppia species, based on morphological characteristics (modified from Zhao and Wu, 2008), is reported in Appendix 2. The key has been modified adding $R$. drepanensis characteristics (Triest and Symoens, 1991; Sfriso, 2008).

\subsection{Genetic diversity and chromosome numbers}

Only recently, particular attention has been paid to molecular phylogenetics and population genetic diversity (Triest and Symoens, 1991; Triest and Sierens, 2009a,b, 2010, 2013, 2014; Ito et al., 2010, 2013). A first study on isozymes at European and Mediterranean level revealed a cluster of four genetic groups, a low level of polymorphism within $R$. maritima being a separated taxon, and a slight difference between $R$. cirrhosa and $R$. drepanensis (Triest and Symoens, 1991). Isozymes make it difficult to reveal a genetic structure of populations because most populations appear uniform, whereas multiclonal populations are not distinct, probably due to a scarce sampling of enzyme genes (Triest and Symoens, 1991). Similarly, low or absent enzyme polymorphism has been found in seagrasses such as Zostera L. (De Heij and Nienhuis, 1992; Williams and Orth, 1998) and Posidonia K. Koenig (Capiomont et al., 1996). These aquatic plant groups display rather low allozymic variability, due to the extensive clonal spread (McMillan, 1991; Triest, 1991) and limited hydrophilous pollination (Les, 1988). The lack of genetic variability in genes coding for enzymes, probably lies at the basis of the general difficulties in distinguishing the genetic structure of plant populations from saline habitats such as Ruppia, seagrasses and mangrove trees (Triest, 2008). In general, aquatic plants inhabiting lagoons have very low allozyme diversities (Triest, 1991, 2008). The hypothesis, stated in Triest (2008) (i.e., flowering plants from saline aquatic environments retain lower enzyme polymorphism in their populations, due to constraints on evolutionary transition into the stressful marine environment), should be further tested using DNA polymorphism when coding regions of enzyme genes.

Recently, cpDNA (chloroplast DNA) investigations revealed the presence of 16 haplotypes across the European part of the Mediterranean, one corresponding to $R$. maritima and 15 corresponding to various morphological forms of $R$. cirrhosa all together referred to as the "R. cirrhosa s.l. complex", which includes the $R$. drepanensis (or $R$. cirrhosa var. drepanensis) populations (Triest and Sierens, 2010). Those investigations revealed more chloroplast DNA variability at the level of species than would be expected from the traditional view of only two widespread taxa ( $R$. maritima and $R$. cirrhosa) and a more restricted taxon, $R$. drepanensis (Triest and Sierens, 2009a,b). R. maritima shows a different evolutionary development from other Ruppia haplotypes or Mediterranean taxa and might be more rare than previously supposed (Triest and Sierens, 2009a,b). Ito et al. (2010) proposed a world-wide R. maritima complex without recognizing the evidence of a distinct $R$. maritima taxon and a polymorphic $R$. cirrhosa complex in Europe (Triest and Sierens, 2009a,b, 2010). This hypothesis was updated with phylogenetic analyses of additional Mediterranean samples (Ito et al., 2013) which confirmed the presence of three taxa and hybrids found by Triest and Sierens (2010, 2013). Conclusions about relationships, hybrids and polyploidy are exactly the same for both author groups (Triest and Sierens, 2013, 2014; Ito et al., 2013), but a different name is given to the putative species complex. Triest and Sierens (2009a,b, 2010, 2013, 2014) adhere to the nomenclature of a well-separated diploid $R$. maritima taxon close to an unresolved polymorphic complex of tetraploid $R$. cirrhosa that also includes $R$. drepanensis and traces of hybrid origin. Ito et al. (2013) consider a single world-wide $R$. maritima complex including all phylogenetic clades, even those supported by high bootstrap values. Most of the samples analyzed by Ito et al. (2013) were morphologically identified as $R$. maritima, even outside the clade of the diploid $R$. maritima. It is very unlikely that these world-wide "so-called" $R$. maritima samples (e.g., 'utahian', 'tetraploid alfa', 'tetraploid beta', 'tetraploid gamma' and 'filifolia' in Fig. 3 of Ito et al., 2013) belong to the same taxon as the type specimen of $R$. maritima from the Baltic sea ('diploid' in Fig. 3 of Ito et al., 2013). It may be that the label of Ruppia superficially given when a detailed morphological analysis of all plant parts lacks (Den Hartog, personal communication), is a cause of confusion.

The high cpDNA diversity of Ruppia in the western Mediterranean basin, representing a center of Ruppia diversity, suggests a west-east gradient which can be explained as a historical dissemination of a limited number of haplotypes from the western to the eastern Mediterranean basin (Triest and Sierens, 2010, 2014). CpDNA analyses highlighted the maternal dispersal and spreading through seeds and rhizomes, which for Ruppia are more important than dispersal by pollen, whose flow is mainly restricted to a single waterbody as mature pollen floats on the water surface. It has also been proposed that both haplotype recruitment and local dispersal of Ruppia propagules by water movement is constrained, or that the genotypes undergo an environmental selection depending on the habitat (Triest and Sierens, 2009a).

The original idea of only two widespread species, $R$. cirrhosa and $R$. maritima (Reese, 1962; Den Hartog, 1971; Dandy, 1980), suggested the presence of a uniform population structure, the separation of which possibly was caused by a long-distance dispersal mediated by birds as generally expected for water plants (Santamaría, 2002). However, cpDNA investigations minimize the effect of strong bird-mediated dispersal (Triest and Sierens, 


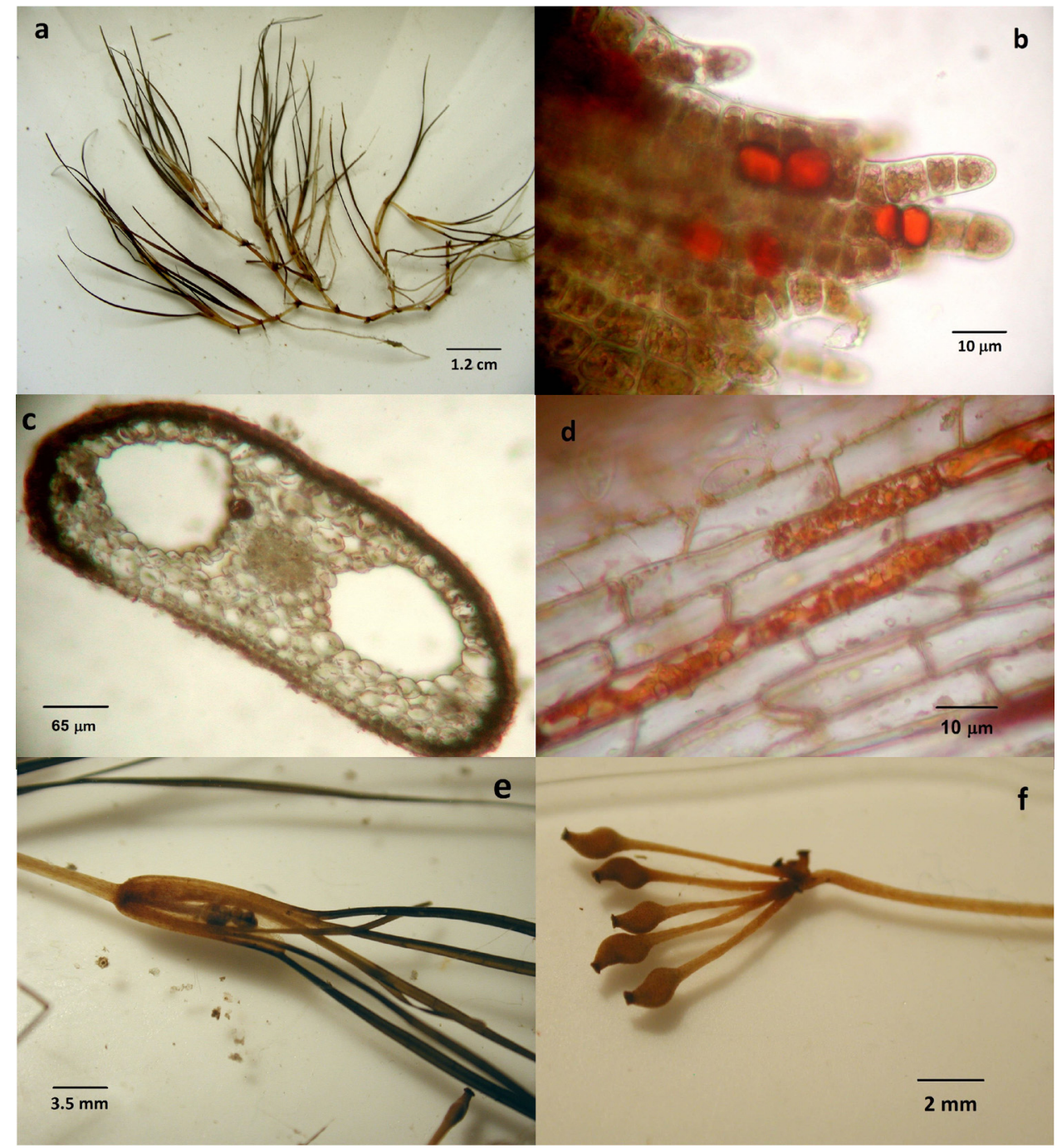

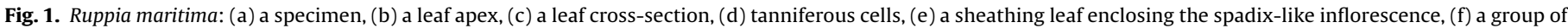
achens.

2009a,b). Moreover, it has been observed that the less fertile haplotypes showed the largest and most continuous distribution (Triest and Sierens, 2013). Therefore, it has been proposed that water movement, or something similar, during and after the last glacial period, determined the distribution of Ruppia haplotypes that do not set seeds very frequently in the Mediterranean (e.g., R. cirrhosa). In contrast, haplotypes that produce numerous seeds (e.g., $R$. drepanensis and $R$. maritima) were mainly dispersed by bird mediation (Triest and Sierens, 2009b, 2013, 2014).

Differences in chromosome numbers have also been observed. Diploid $(2 n=20)$ and tetraploid $(2 n=40)$ races have been reported from several regions of the world, whereas triploids $(2 n=30)$ and hexaploids $(2 n=60)$ races have been found only occasionally (Talavera et al., 1993). Previously, the two widespread species, $R$. maritima and $R$. cirrhosa, were considered as diploid and polyploid, respectively (Reese, 1962). However, Van Vierssen et al. (1981) have recognized $R$. maritima as both diploid and tetraploid and $R$. cirrhosa as tetraploid, and Cirujano (1986) considered $R$. maritima as tetraploid and $R$. cirrhosa as diploid. Moreover, Triest and Symoens (1991) recognized diploid and tetraploid entities in both morphological species.

In the Western Mediterranean diploid R. drepanensis, tetraploid $R$. cirrhosa and diploid and tetraploid $R$. maritima (Talavera et al.,
1993; Triest and Sierens, 2009a) were recorded. In north-western Spain and in Sicily the diploid R. maritima was found (Marchioni Ortu, 1982; Aedo and Fernández Casado, 1988) whereas in Central Spain the tetraploid $R$. maritima and the diploid $R$. drepanensis were recorded (Cirujano, 1986). However, the chromosome counts reported in the literature should be re-evaluated in the context of the nuclear microsatellite and cpDNA haplotypic variation in case of introgressed hybrids (Triest and Sierens, 2014).

The presence of 20 bivalents in $R$. maritima and $R$. cirrhosa at diakinesis would support the hypothesis of an allopolyploid origin for tetraploid races of these species (Talavera et al., 1993).

Moreover, since long arms in large chromosomes do not recombine during meiosis, these regions of the genome might have an adaptive value (Stebbins, 1971; Talavera et al., 1993).

\subsection{Distribution}

The presence of $R$. cirrhosa has been reported from most countries bordering the Mediterranean Sea where R. maritima and $R$. drepanensis are much less common (Table S2).

However, since misidentifications especially of $R$. maritima frequently occur in floristic studies as well as in Genbank (Triest and Sierens, 2014), an accurate identification of Ruppia populations is 


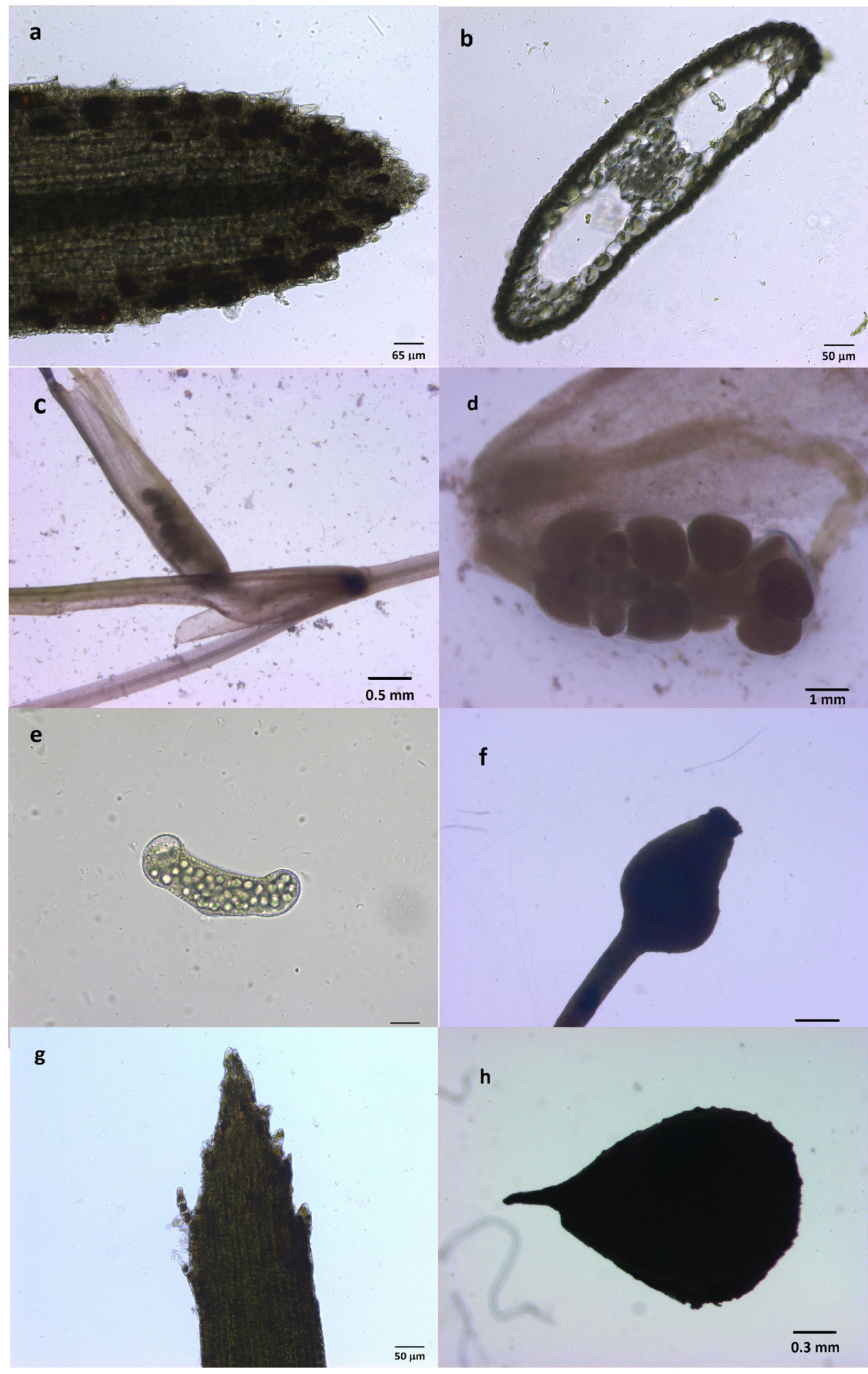


drepanensis: $(\mathrm{g})$ a leaf apex, $(\mathrm{h})$ an achen.

needed prior to depict the real distribution of the species. Recently, Triest and Sierens (2014) identified three haplogroup lineages: a $R$. cirrhosa complex (including $R$. drepanensis and ancient hybrid lineages), a $R$. maritima group and some hybrids with most of the diversity occurring in the southern Mediterranean Sea. On the basis of 20 haplotypes, the authors found that the R. cirrhosa complex consists of two common related haplogroups ( $B$ and $C$ ), a more rare and less related haplogroup A ( $R$. drepanensis), an ancient hybrid haplogroup E (consisting of several distant evolutionary lineages) and more recent introgressed hybrids with chloroplast capture. In particular, hybrids between female $R$. cirrhosa and male $R$. maritima or male of $R$. cirrhosa complex at several locations (Southern 
Atlantic coast of France, Western Mediterranean coast of Spain and island of Menorca) were observed. A recent northward (Atlantic, North Sea and Baltic coastlines) expansion of $R$. cirrhosa was also observed. The diploid $R$. maritima complex (haplogroup D) was very distinct from the common tetraploid $R$. cirrhosa (Triest and Sierens, 2014).

According to literature, in the extra-Mediterranean areas $R$. maritima seems to be more common than $R$. cirrhosa (Table S3). However, these $R$. maritima populations should be carefully verified. $R$. maritima is the only species recorded in North America (Verhoeven, 1979; Kantrud, 1991; Onuf et al., 2003; Lirman et al., 2008; Cho and Poirrier, 2005; Strazisar et al., 2013), along the South western coasts of Canada (Harrison, 1982) and in India (Rodrigues et al., 2009). In Portugal, in Central and South America and in South Africa, both $R$. cirrhosa and $R$. maritima are present (Póvoa dos Reis, 1973; Verhoeven, 1979; Bortolus et al., 1998; Duarte et al., 2002; Lopez-Calderon et al., 2010; Vromans et al., 2013; Triest and Sierens, 2014). In Australia and New Zealand R. maritima, $R$. tuberosa, $R$. polycarpa and $R$. megacarpa are present (Congdon and McComb, 1979; Verhoeven, 1979; Brock, 1982a,b; Jacobs and Brock, 1982; Kim et al., 2013).

Dispersal certainly plays a significant role in determining the distribution of Ruppia species. According to Verhoeven (1979), detached vegetative parts of the plants free-float for a long time before landing to the bottom, where they settle rapidly as observed by Orth et al. (1994) for Zostera marina L. The same authors also stated that the ripe seeds can be spread by drifting plant parts.

After desiccation, dried plant parts with seeds are dispersed by the wind over considerable distances. Also, several bird species contribute to dispersal. According to Clausen et al. (2002) long-distance dispersal would be rare and the gene flow caused by present day dispersal would play a minor role in comparison to past events. Green et al. (2002) pointed out that, even though only few seeds remain trapped in the intestinal system of birds, they may represent an important dispersal event for clonal plants like Ruppia.

\subsection{Growth cycle}

$R$. cirrhosa is an annual/perennial species occurring in a wide range of salinity, depth, light and temperature conditions (Verhoeven, 1975, 1979; Cagnoni, 1997; Menéndez, 2002; Menéndez et al., 2002; Agostini et al., 2003; Mannino and Sarà, 2006; Mannino, 2010; Obrador and Pretus 2010; Mannino and Graziano, 2014), in both permanent and temporary lagoons in coastal areas of the NW Mediterranean Sea (Verhoeven, 1979; Gesti, 2000).

After a quiescent period, the length of which is related to temperature, vegetative growth starts with the formation of horizontal rhizomes with monopodial branching. After some time, the horizontal growth changes to vertical, and as soon as flowering begins, branching becomes sympodial (Graves, 1908). Flowering and fructification are more abundant in small water bodies due to the absence of turbulence. $R$. cirrhosa mainly uses "epihydrophilous" (i.e., it takes place at the water surface) cross-pollination, generally less efficient in deep waters (Cook, 1982; Gamerro, 1968; Verhoeven, 1979; Pettit, 1984; Cox, 1988; Cirujano and GarcíaMurillo, 1992; Gesti et al., 2005). Since R. cirrhosa brings its flowers up to the water surface, the peduncle length varies according to water depth. In permanent water basins it has a luxuriant vegetative and a moderate generative development. For dispersal, seed transportation by birds and water movement is important. At the end of the vegetative cycle, the shoot tips of $R$. cirrhosa may stop growing vertically and begin to grow horizontally, forming short rhizomes with small roots at each node. These vegetative portions show strong positive geotropism (Verhoeven, 1979; Menéndez et al., 1993).
In temporarily flooded areas, the life cycle must be completed before the basin is dried. Flowering takes place later than in the permanently flooded basins, lasts much shorter, and the production of fruits is higher (Gesti et al., 2005). Also Vromans et al. (2013) observed in warm temperate temporarily estuaries in South Africa the reproductive period of $R$. cirrhosa lasted as long as habitats were permanently flooded and the species only survived the dry phase by seeds.

The growth cycle of $R$. maritima is also significantly affected by environmental conditions. Cho and Poirrier (2005), for example, analyzing some populations from North America observed a positive correlation with high water temperatures. It was also observed that $R$. maritima can grow in unstable intertidal habitats (South America), requiring a higher reproductive resource allocation, and colonize abandoned habitats (i.e., Indian saltpans) (Richardson, 1980; Costa and Seeliger, 1989; Rodrigues et al., 2009).

$R$. maritima mainly hibernates as seed, but it also displays quiescent vegetative rhizomes in flooded environments. Its generative development is much more luxuriant than that of $R$. cirrhosa, flowering starts earlier and is very abundant. $R$. maritima has a "hypohydrophilous" self-pollination which takes place underwater, but cross-pollination is also possible (Verhoeven, 1979; Richardson, 1983). Under-water (hypohydrophilous) and abovewater (epihydrophilous) pollination are both possible in relation to water level changes (Verhoeven, 1979; Lacroix and Kemp, 1997). This pattern fits very well the hypothesis of evolution of underwater pollination from the aerial one (Philbrick, 1988; Philbrick and Les, 1996; Lacroix and Kemp, 1997). This type of pollination is very successful and leads a high seed production, particularly in ephemeral lagoons or estuarine environments (Verhoeven, 1979; Cho and Poirrier, 2005; Kahn and Durako, 2005; Triest and Sierens, 2009a). Desiccation can induce seed dormancy that vice versa can be interrupted by exposure to water (Cho and Sanders, 2009). In temporary habitats, the vegetative parts die and only seed hibernation occurs. Seeds can resist both harsh conditions such as desiccation (Kantrud, 1991; Cho and Sanders, 2009) and even gut-passages of waterfowl and fish, thus allowing a long-distance dispersal (Agami and Waisel, 1988; Figuerola et al., 2002; Charalambidou et al., 2003; Figuerola and Green, 2004). It has been observed that the ingestion of $R$. maritima seeds by birds may positively affect their viability and/or germination rate (Figuerola et al., 2002). However, germination rate increases after ingestion are not necessarily beneficial for the plant, and the final outcome depends on complex interactions with other factors such as herbivore abundance (Figuerola and Green, 2004).

\subsection{Ecology}

The genus Ruppia has a well-defined ecological niche, inhabiting brackish and saline shallow aquatic habitats. Possibly, Ruppia is suffering from competition by other water plants outside this brackish range (Verhoeven, 1979; Menéndez and Peñuelas, 1993).

Water level, salinity fluctuations, redox status of surface sediments, wave exposure, self-shading, temperature, desiccation and light availability, with water transparency improving its competitiveness, are generally considered the main factors affecting the distribution and growth of $R$. cirrhosa (Verhoeven, 1979, 1980b; Menéndez and Comín, 1989; Menéndez and Peñuelas, 1993; Adams and Bate, 1994; Santamaría and Hootsmans, 1998; Calado and Duarte, 2000; Azzoni et al., 2001; Menéndez et al., 2002; Gesti et al., 2005; Obrador et al., 2007; Obrador and Pretus, 2008, 2010; Sfriso et al., 2009a; Sfriso, 2010).

In particular, $R$. cirrhosa tolerates a wide range of water temperature (mainly between 5 and $30^{\circ} \mathrm{C}$ ) and salinity (1.5-60 psu) (Verhoeven, 1979; Menéndez et al., 2002; Malea et al., 2004; Obrador and Pretus, 2010; Mannino and Graziano, 2014). The halo- 
tolerance, enhanced by the cytoplasm accumulation of the amino acid proline (Stewart and Lee, 1974; Cavalieri and Huang, 1979; Signorini et al., 2008), makes $R$. cirrhosa more competitive at high salinities (Comín et al., 1991, 1995; Adams and Bate 1994; Murphy et al., 2003; Casagrande and Boudouresque, 2007; Shili et al., 2007; Obrador and Pretus, 2010).

Even though $R$. maritima may survive high salinity fluctuations (Kantrud, 1991), its optimum range is narrower (0.3-15 psu) than that of $R$. cirrhosa (up to 60 psu) (Verhoeven, 1975, 1979). Pulsing salinities may negatively affect $R$. maritima growth rates and reproductive efforts (Verhoeven, 1979; Kantrud, 1991; Bonis et al., 1993; La Peyre and Rowe, 2003). In contrast, populations of R. maritima in North America tolerate both low and high salinities quite well (Lirman et al., 2008; Strazisar et al., 2013).

In general, Ruppia plants prefer mud and clay sediments, rich in organic material (Giusti and Marsili-Libelli, 2005; Sfriso et al., 2009a; Sfriso, 2010) and have a high resilience (sensu Connell and Sousa, 1983). Eutrophication may negatively affect Ruppia survival (Sand-Jensen and Borum, 1991; Sfriso et al., 2007, 2009a,b; Menéndez et al., 1993; Comín et al., 1995; Sfriso and Marcomini, 1996; Viaroli et al., 1996; Azzoni et al., 2001; Teixeira da Silva and Asmus, 2001; Menéndez et al., 2002; Giusti and Marsili-Libelli, 2005; Pergent et al., 2006; Sfriso, 2010), leading to the bed regression or replacement by fast growing thionitrophilous macroalgae, phytoplankton and/or cyanobacteria (Stevenson, 1988; SandJensen and Borum, 1991; Sfriso et al., 2009b).

\subsection{Biomass and production}

In shallow waters the productivity of macrophytes such as Ruppia species plays an important structural and functional role (Mann, 1972; Wetzel, 1975; Sfriso and Facca, 2007; Obrador and Pretus, 2012, 2013) also affecting the carbon cycle (Duarte et al., 2005; Sfriso et al., 2005; Obrador and Pretus, 2012). However, although $R$. cirrhosa productivity is high, its biomass is not significant in the food chain because of the low palatability, due to the presence of several tanniferous cells (Obrador and Pretus, 2012).

$R$. cirrhosa density (from 4166 to 78,210 shoot $\mathrm{m}^{-2}$ ), biomass (from 12 to $1408 \mathrm{~g} \mathrm{DW} \mathrm{m}^{-2}$ ) and production (from 36 to $361 \mathrm{~g} \mathrm{C} \mathrm{m}^{-2} \mathrm{yr}^{-1}$ ) have been thoroughly investigated in last decades (Verhoeven, 1980b; Menéndez and Comín, 1989; Menéndez and Peñuelas, 1993; Viaroli et al., 1996; Calado and Duarte, 2000; Duarte et al., 2002; Menéndez et al., 2002; Gesti et al., 2005; Mannino and Sarà, 2006; Obrador et al., 2007; Obrador and Pretus, 2010; Dhib et al., 2013; Vromans et al., 2013; Tables S4 and S5). Most of the $R$. cirrhosa production estimates are based on biomass variations, sometimes including estimates of leaf loss due to mortality during the growing period, as suggested by Menéndez (2002).

Biotic and abiotic external factors, particularly light availability, are important drivers for $R$. cirrhosa production (Calado and Duarte, 2000; Obrador, 2009). Fig. 3 summarizes the relationship between the annual production of $R$. cirrhosa and the depth of the water column for a set of Mediterranean coastal lagoons. A clear negative correlation was observed, suggesting that light is an important limiting factor in determining the annual production and the colonization of shallower bottoms.

The high production of Ruppia can lead to carbon limitation $(\mathrm{pH}>9)$ during the summer productivity peaks (Obrador, 2009). The ability to use $\mathrm{HCO}_{3}{ }^{-}$probably is an important adaptative mechanism for this plant that can also grow in $\mathrm{CO}_{2}$-depleted waters (Peñuelas and Menéndez, 1990; Hellblom and Axelsson, 2003; Obrador, 2009).

A few data are available on Mediterranean populations of $R$. maritima, while populations from extra-Mediterranean areas have been widely investigated (Gonzalez Gutiérrez, 1977; Howard-Williams and Liptrot, 1980; Verhoeven, 1980b; Flores-Verdugo et al., 1988;

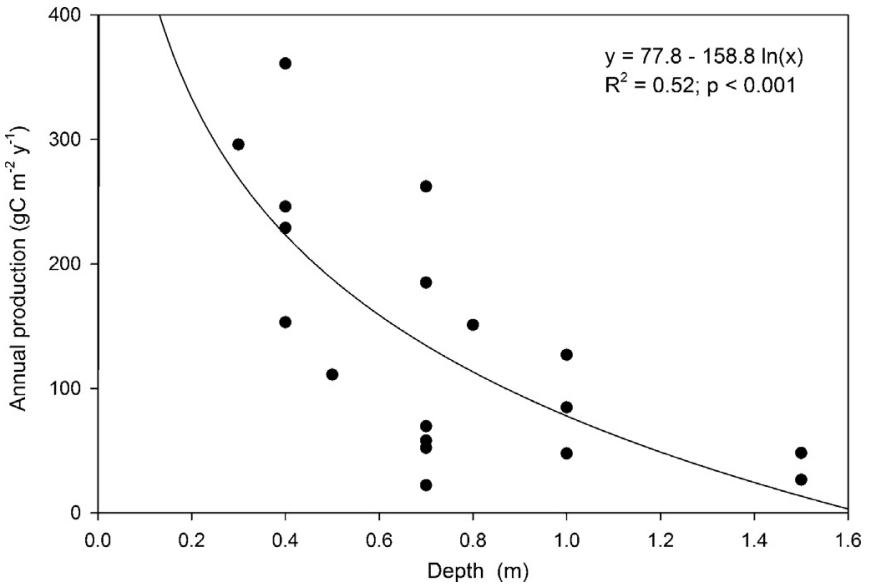

Fig. 3. Annual production of Ruppia cirrhosa as a function of water depth from different coastal lagoons. The lagoons corresponding to bibliographic data are Valle Smarlacca, Italy (Azzoni et al., 2001; Bartoli et al., 2008); Llacuna de la Tancada, Spain (Menéndez and Comín, 1989; Menéndez, 2002); Albufera des Grau, Spain (Obrador et al., 2007; Obrador and Pretus, 2010); Lake Ichkeul, Tunisia (Casagranda and Boudouresque, 2007); Tvärminne, Finland (Verhoeven, 1980); Camargue, France (Verhoeven, 1980b); Coastal ponds, Netherlands (Verhoeven, 1980b); Certes fishponds, France (Viaroli et al., 1996; Bachelet et al., 2000); Santo André lagoon, Portugal (Calado and Duarte, 2000); Biguglia lagoon, Italy (Pasqualini et al., 2006; Pergent et al., 2006); Sta Giulia lagoon, Italy (Pergent et al., 2006); Fra Ramon, Spain (Gesti et al., 2005).

Cho and Poirrier, 2005; Lopez-Calderon, 2010, Tables S4 and S5). $R$. maritima biomass and productivity are affected by changes of environmental conditions (e.g., temperature, eutrophication, light availability, water movement and basin desiccation), with consequent modifications of local trophic networks, and by grazing (Congdon and Mccomb, 1979; Verhoeven, 1979, 1980b; Bortolus et al., 1998; Milchakova, 1999; Cho et al., 2009; Lopez-Calderon et al., 2010 and references therein). Moreover, Verhoeven (1980b) observed that the biomass peak of annual populations in temporary brackish habitats (between 25 and $290 \mathrm{~g} \mathrm{AFDW} \mathrm{m}^{-2}$ ) depends on the time the habitat takes to dry.

\section{Acknowledgements}

The authors thank Dr. Orietta Zucchetta for improving the English text and the anonymous reviewers for helpful comments and suggestions. Special thanks go to the Editor for his patience in reviewing the English language and for his critical comments and suggestions that greatly improved the final version of the text.

\section{Appendix A. Supplementary data}

Supplementary data associated with this article can be found, in the online version, at http://dx.doi.org/10.1016/j.aquabot. 2015.02.005.

\section{References}

Adams, J., Bate, G., 1994. The tolerance to desiccation of the submerged macrophytes Ruppia cirrhosa (Petagna) Grande and Zostera capensis Setchell. J. Exp. Mar. Biol. Ecol. 183, 53-62.

Aedo, C., Fernández Casado, M.A., 1988. The taxonomic position of Ruppia populations along the Cantabrian coast. Aquat. Bot. 32, 187-192.

Agami, M., Waisel, Y., 1988. The role of fish in distribution and germination of seeds of the submerged macrophytes Najas marina L. and Ruppia maritima L. Oecologia 76, 83-88.

Agostini, S., Capiomont, A., Marchand, B., Pergent, G., 2003. Distribution and estimation of basal area coverage of subtidal seagrass meadows in a Mediterranean coastal lagoon. Estuarine Coastal Shelf Sci. 56, 1021-1028.

Ascherson, P., Graebner, P., 1907. In: Engler, A. (Ed.), Potamogetonaceae. Das Pflanzenreich Heft 31, Leipzig, pp. 1-184. 
Azzoni, R., Giordani, G., Bartoli, M., Welsh, D.T., Viaroli, P., 2001. Iron, sulphur and phosphorus cycling in the rhizosphere sediments of a eutrophic Ruppia cirrhosa meadow (Valle Smarlacca, Italy). J. Sea Res. 45, 15-26.

Bachelet, G., De Montaudouin, X., Auby, I., Labourg, P.J., 2000. Seasonal changes in macrophyte and macrozoobenthos assemblages in three coastal lagoons unde varying degrees of eutrophication. ICES J. Mar. Sci. 57, 1495-1506.

Bartoli, M., Nizzoli, D., Castaldelli, G., Viaroli, P., 2008. Community metabolism and buffering capacity of nitrogen in a ruppia cirrhosa meadow. J. Exp. Mar. Biol. Ecol. 360, 21-30.

Bonis, A., Grillas, P., Vanwijck, C., Lepart, J., 1993. The effects of salinity on the reproduction of coastal submerged macrophytes in experimental communities. J. Veg. Sci. 4, 461-468.

Bortolus, A., Iribarne, O.O., Martinez, M.M., 1998. Relationship between waterfow and the seagrass Ruppia maritima in a southwestern Atlantic coastal lagoon. Estuaries 21, 710-717.

Brock, M.A., 1982a. Biology of the salinity torelant genus Ruppia L. in saline lakes in south Australia. I. Morphological variation within and between species and ecophysiology. Aquat. Bot. 13, 219-248.

Brock, M.A., 1982b. Biology of the salinity torelant genus Ruppia L. in saline lakes in south Australia. II. Population ecology and reproductive biology. Aquat. Bot. 13, 249-268.

Cagnoni, S., 1997. Dinamiche di Sviluppo di Fitocenosi a Ruppia cirrhosa (Petagna) Grande e Zostera noltii Hornem. in un Chiaro di Barena in Relazione ai loro Microambienti di Elezione. University Ca' Foscari of Venice (Thesis).

Calado, G., Duarte, P., 2000. Modelling growth of R. cirrhosa. Aquat. Bot. 68, 29-44.

Capiomont, A., Sandmeier, M., Caye, G., Meinesz, A., 1996. Enzyme polymorphism in Posidonia oceanica, a seagrass endemic to the Mediterranean. Aquat. Bot. 54 265-277.

Casagranda, C., Boudouresque, C.F., 2007. Biomass of Ruppia cirrhosa and Potamogeton pectinatus in a Mediterranean brackish lagoon, Lake Ichkeul, Tunisia. Fundam. Appl. Limnol. Arch. Hydrobiol. 168, 243-255.

Cavalieri, A.J., Huang, A.H.C., 1979. Evaluation of proline accumulation in the adaptation of diverse species of marsh halophytes to the saline environment. Am. J. Bot. 66, 307-312.

Charalambidou, I., Santamaría, L., Langevoord, L., 2003. Effect of ingestion by five avian dispersers on the retention time, retrieval and germination of Ruppia maritima seeds. Funct. Ecol. 17, 747-753.

Cho, H.J., Poirrier, M.A., 2005. Seasonal growth and reproduction of Ruppia maritima L. s.l, in Lake Pontchartrain, Louisiana. Aquat. Bot. 81, 37-49.

Cho, H.J., Sanders, Y.L., 2009. Note on organic dormancy of estuarine Ruppia maritima seeds. Hydrobiologia 617, 197-201.

Cho, H.J., Biber, P., Nica, C., 2009. The rise of Ruppia in seagrass beds: changes in coastal environment and research needs. In: Drury, E.K., Pridgen, T.S. (Eds.), Handbook on Environmental Quality. Nova Science, New York, pp. 1-15.

Cirujano, S., García-Murillo, P., 1990. Ruppiaceae. Fontqueria 28, 159-165.

Cirujano, S., García-Murillo, P., 1992. El género Ruppia en la Península Ibérica. Quercus 74, 14-21.

Cirujano, S., 1986. El género Ruppia L. (Potamogetonaceae) en la Mancha (España). Bolet. da Soc. Brot. Série 2 59, 293-303.

Clausen, P., Nolet, B.A., Fox, A.D., Klaassen, M., 2002. Long-distance endozoochorous dispersal of submerged macrophyte seeds by migratory waterbirds in northern Europe - a critical review of possibilities and limitations. Acta Oecol. 23, 191-203.

Comín, F.A., Menéndez, M., Martín, M., 1991. Short-term effects of decreasing water discharge on the chemical and biological characteristics of eutrophic coastal lagoons. Ecosystem research in freshwater environment recovery. Mem. Ist. Ital. Idrobiol. 48, 9-22.

Comín, F.A., Rodó, X., Menéndez, M., 1993. Spatial hetereogeneity of macrophytes in Lake Gallocanta (Aragón, NE Spain). Hydrobiologia 267, 169-178.

Comín, F.A., Martín, M., Menéndez, M., Romero, J.A., Herrera-Silveira, J.A., 1995. Integrated management of a coastal lagoon in the Ebro Delta. In: Ozhan, E. (Ed.), Proceedings of the 2nd International Conference on the Mediterranean Coast (MEDCOAST 95), 883-895.

Congdon, R.A., McComb, A.J., 1979. Productivity of Ruppia: seasonal changes and dependence on light in an Australian estuary. Aquat. Bot. 6, 121-132.

Connell, J.H., Sousa, W.P., 1983. On the evidence needed to judge ecological stability or persistence. Am. Nat. 121, 789-824

Cook, C.D.K., 1982. Pollination mechanisms in the Hydrocharitaceae. In: Symoens, J.J., Hooper, S.S., Compère, P. (Eds.), Studies on Aquatic Vascular Plants. Royal Botanical Society of Belgium, Brussels, pp. 1-15

Costa, C.S.B., Seeliger, U., 1989. Vertical distribution and resource allocation of Ruppia maritima L. in a southern Brazilian estuary. Aquat. Bot. 33, 123-129.

Cox, P.A., 1988. Hydrophilous pollination. Ann. Rev. Ecol. Syst. 19, 261-280.

Cronquist, A., 1981. An Integrated System of Classification of Flowering Plants. Columbia University Press, New York.

Dahlgren, R.M.T., Clifford, H.T., Yeo, P.F., 1985. The Families of the Monocotyledons Springer-Verlag, Berlin.

Dandy, J., 1980. Ruppia. In: Tutin, T.G., Heywood, H., Burges, N.A., Moore, D.M., Valentine, D.H., Walters, S.M., Webb, D.A. (Eds.), Flora Europaea. Alismataceae to Orchidaceae, Vol. V, 1st ed. Cambridge University Press, Oxford, p. 11.

De Heij, H., Nienhuis, P.H., 1992. Intraspecific variation in isozyme patterns of phenotypically separated populations of Zostera marina L. in the south-western Netherlands. J. Exp. Mar. Biol. Ecol. 161, 1-14.

De Oliveira, E.C.F., Pirani, J.R., Giulietti, A.M., 1983. The Brazilian seagrasses. Aquat. Bot. 16, 251-267.
Den Hartog, C., Kuo, J., 2006. Taxonomy and biogeography of seagrasses. In: Larkum, A.W.D., Orth, R.J., Duarte, C. (Eds.), Seagrasses: Biology, Ecology and Conservation. Springer, Dordrecht, pp. 1-23.

Den Hartog, C., 1971. De Nederlandse Ruppia-soorten. Gorteria 5, 148-153.

Den Hartog, C., 1981. Aquatic plant communities of poikilosaline waters. Hydrobiologia 81, 15-22.

Dhib, A., Ben Brahim, M., Turki, S., Aleya, L., 2013. Contrasting key roles of Ruppia cirrhosa in a southern Mediterranean lagoon: reservoir for both biodiversity and harmful species and indicator of lagoon health status. Mar. Pollut. Bull. 76, $116-127$.

Duarte, P., Bernardo, J.M., Costa, A.M., Macedo, F., Calado, G., Cancela da Fonseca, L., 2002. Analysis of coastal lagoon metabolism as a basis for management. Aquat. Ecol. 36, 3-19.

Duarte, C., Middelburg, J., Caraco, N., 2005. Major role of marine vegetation on the oceanic carbon cycle. Biogeosciences 2, 1-8.

Figuerola, J., Green, A.J., 2004. Effects of seed ingestion and herbivory by waterfowl on seedling establishment: a field experiment with wigeongrass Ruppia maritima in Doñana, south-west Spain. Plant Ecol. 173, 33-38.

Figuerola, J., Green, A., Santamaría, L., 2002. Comparative dispersal effectiveness of wigeongrass seeds by waterfowl wintering in south-west Spain: quantitative and qualitative aspects. J. Ecol. 90, 989-1001.

Flores-Verdugo, F.J., Day Jr., J.W., Mee, L., Briseño-Dueñas, R., 1988. Phytoplankton production and seasonal biomass variation of seagrass Ruppia maritima L., in a tropical Mexican lagoon with an ephemeral inlet. Estuaries 11, 51-56.

Gamerro, J.C., 1968. Observaciones sobre la biologia floral y morfologia de la potamogetonacea Ruppia cirrhosa (Petag.) Grande (=R. spiralis L. ex Dum.) Darwiniana 14, 575-607.

Gesti, J., Badosa, A., Quintana, X.D., 2005. Reproductive potential in Ruppia cirrhosa (Petagna) Grande in response to water permanence. Aquat. Bot. 81, 191-198.

Gesti, J., 2000. El Poblament Vegetal dels Aiguamolls de l'Empordà: Efectes de la Creació del Parc Natural sobre la Vegetació i Propostes per a una Gestió dels Hàbitats. University of Girona (Ph.D. Dissertation).

Giusti, E., Marsili-Libelli, S., 2005. Modelling the interactions between nutrients and the submersed vegetation in the Orbetello lagoon. Ecol. Model. 184, $141-161$.

Gonzalez Gutiérrez, M., 1977. Observaciones sobre un comportamiento atipico de Ruppia maritima L. en una laguna costera tropical. Bol. Soc. Bot. Mex. 37, 53-68.

Graves, A.H., 1908. The morphology of Ruppia maritima. Trans. Conn. Acad. Arts Sci. 14, 59-170.

Green, P., Short, F.T., 2003. World Atlas of Seagrasses. UNEP-WCMC University of California Press, Berkeley and Los Angeles, p.298

Green, A.J., Figuerola, J., Sánchez, M.I., 2002. Implications of waterbird ecology for the dispersal of aquatic organisms. Acta Oecol. 23, 177-189.

Hagström, J.O., 1911. Three species of Ruppia. Bot. Not. 11, 137-144

Hara, H., 1983. Comments on the east asiatic plants (12). J. Jpn. Bot. 58, 321-330.

Harrison, P.G., 1982. Seasonal and year-to-year variations in mixed intertidal populations of Zostera japonica Aschers. \& Graebn. and Ruppia maritima L. s.l. Aquat. Bot. 14, 357-371.

Hellblom, F., Axelsson, L., 2003. External $\mathrm{HCO}_{3}{ }^{-}$dehydration maintained by acid zones in the plasmamembrane is an important component of the photosynthetic carbon uptake in Ruppia cirrhosa. Photosynth. Res. 77, 173-181.

Howard-Williams, C., Liptrot, M.R.M., 1980. Submerged macrophyte communities in a brackish South African estuarine-lake system. Aquat. Bot. 9, 101-116.

Ito, Y., Ohi-Toma, T., Murata, J., Tanaka, M., 2010. Hybridization and polyploidy of an aquatic plant Ruppia (Ruppiaceae), inferred from plastid and nuclear DNA phylogenies. Am. J. Bot. 97, 1156-1167.

Ito, Y., Ohi-Toma, T., Murata, J., Tanaka, M., 2013. Comprehensive phylogenetic analyses of the Ruppia maritima complex focusing on taxa from the Mediterranean. J. Plant Res. 126, 753-762.

Jacobs, S.W.L., Brock, M.A., 1982. A revision of the genus Ruppia (Potamogetonaceae) in Australia. Aquat. Bot. 14, 325-337.

Kahn, A.E., Durako, M.J., 2005. The effect of salinity and ammonium on seed germination in Ruppia maritima from Florida Bay. Bull. Mar. Sci. 77, 453-458.

Kantrud, H.A., 1991. Widgeongrass (Ruppia maritima L.): a literature review. U.S. fish and wildlife service. Fish Wildl. Res. 10, p. 58.

Kim, D.H., Aldridge, K.T., Brookes, J.D., Ganf, G.G., 2013. The effect of salinity on the germination of Ruppia tuberosa and Ruppia megacarpa and implications for the Coorong: a coastal lagoon of southern Australia. Aquat. Bot. 111, 81-88.

La Peyre, M.K., Rowe, S., 2003. Effects of salinity changes on growth of Ruppia maritima L. Aquat. Bot. 77, 235-241.

Lacroix, C.R., Kemp, J.R., 1997. Developmental morphology of the androecium and gynoecium in Ruppia maritima L.: considerations for pollination. Aquat. Bot. 59, 253-262.

Les, D.H., Cleland, M.A., Waycott, M., 1997. Phylogenetic studies in Alismatidae, II: evolution of marine angiosperms (seagrasses) and hydrophily. Syst. Bot. 22 443-463.

Les, D.H., 1988. Breeding systems, population structure and evolution in hydrophilous angiosperms. Ann. Missouri Bot. Garden 75, 819-835.

Lirman, D., Deangelo, G., Serafy, J., Hazra, A., Smith Hazra, D., Herlan, J., Luo, J., Bellmund, S., Wang, J., Clausing, R., 2008. Seasonal changes in the abundance and distribution of submerged aquatic vegetation in a highly managed coastal lagoon. Hydrobiologia 596, 105-120.

Lopez-Calderon, J., Riosmena-Rodríguez, R., Rodríguez-Baron, J.M., Carrión-Cortez, J., Torre, J., Meling-López, A., Hinojosa-Arango, G., Hernández-Carmona, G., García-Hernández, J., 2010. Outstanding appearance of Ruppia maritima along 
Baja California Sur, México and its influence in trophic networks. Mar. Biodivers. 40, 293-300.

Malea, P., Kevrekidis, T., Mogias, A., 2004. Annual versus perennial growth cycle in Ruppia maritima L.: temporal variation in population characteristics in Mediterranean lagoons (Monolimni and Drana lagoons, Northern Aegean sea) Bot. Mar. 47, 357-366.

Mann, K.H., 1972. Macrophyte production and detritus food chains in coastal waters. Mem. Ist. Ital. Idrobiol. 29, 353-383, Suppl.

Mannino, A.M., Graziano, M., 2014. Differences in the growth cycle of Ruppia cirrhosa (Petagna) Grande in a Mediterranean shallow system. Plant Biosyst., http://dx.doi.org/10.1080/11263504.2014.906511.

Mannino, A.M., Sarà, G., 2006. The effect of Ruppia cirrhosa features on macroalgae and suspended matter in a Mediterranean shallow system. Mar. Ecol. 27, 350-360.

Mannino, A.M., 2010. Temporal and spatial variation of the algal community in a southern Mediterranean shallow system. Cryptogamie Algol. 31, 255-272.

Marchioni Ortu, A., 1982. Numeri cromosomici per la flora italiana: 873-876. Inf. Bot. Ital. 14, 234-237.

McMillan, C., 1991. Isozyme patterning in marine spermatophytes. In: Triest, L. (Ed.), Isozymes in water plants. Op. Bot. Belg. 4, 193-200.

Menéndez, M., Comín, F.A., 1989. Seasonal patterns of biomass variation of Ruppic cirrhosa (Petagna) Grande and Potamogeton pectinatus L. in coastal lagoon. Sci. Mar. 52, 633-638.

Menéndez, M., Peñuelas, J., 1993. Seasonal photosintetic and respiratory responses of Ruppia cirrhosa (Petagna) Grande to changes in light and temperature. Arch. Hydrobiol. 129, 221-230.

Menéndez, M., Forés, E., Comín, F.A., 1993. Decomposition of Ruppia cirrhosa (Petagna) Grande in the sediment of a coastal lagoon. Sci. Mar. 57, 15-21.

Menéndez, M., Hernández, O., Comín, F.A., 2002. Spatial distribution and ecophysiological characteristics of macrophytes in a Mediterranean coastal lagoon. Estuarine Coastal Shelf Sci. 55, 403-413.

Menéndez, M., 2002. Net production of R. cirrhosa in the ebro delta. Aquat. Bot. 73 , 107-113.

Milchakova, N.A., 1999. On the status of seagrass communities in the Black sea. Aquat. Bot. 65, 21-32.

Murphy, L.R., Kinsey, S.T., Durako, M.J., 2003. Physiological effects of short-term salinity changes on Ruppia maritima. Aquat. Bot. 75, 293-309.

Obrador, B., Pretus, J.L., 2008. Light regime and components of turbidity in a Mediterranean coastal lagoon. Estuarine Coastal Shelf Sci. 77, 123-133.

Obrador, B., Pretus, J.L., 2010. Spatiotemporal dynamics of submerged macrophytes in a Mediterranean coastal lagoon. Estuarine Coastal Shelf Sci. 87, 145-155.

Obrador, B., Pretus, J.L., 2012. Budgets of organic and inorganic carbon in a Mediterranean coastal lagoon dominated by submerged vegetation. Hydrobiologia 699, 35-54.

Obrador, B., Pretus, J.L., 2013. Carbon and oxygen metabolism in a densely vegetated lagoon: implications of spatial heterogeneity. Limnetica 32 321-336.

Obrador, B., Pretus, J.L., Menéndez, M., 2007. Spatial distribution and biomass of aquatic rooted macrophytes and their relevance in the metabolism of a Mediterranean coastal lagoon. Sci. Mar. 71, 57-64.

Obrador, B., 2009. Environmental Shaping and Carbon Cycling in a Macrophyte-dominated Coastal Lagoon. University of Barcelona (Ph.D. Dissertation).

Onuf, C.P., Phillips, R.C., Moncreiff, C.A., Raz-Guzman, A., Herrera-Silveira, J.A., 2003. The seagrasses of the Gulf of Mexico. In: Green, E.P., Short, F.T. (Eds.), World Atlas of Seagrasses. University of California Press, Berkeley, pp. 224-233.

Orth, R.J., Moore, K.A., 1988. Distribution of Zostera marina L. and Ruppia maritima L. sensu lato along depth gradients in the lower Chesapeake Bay U.S.A. Aquat. Bot. 32, 291-305.

Orth, R.J., Luckenbach, M.W., Moore, K.A., 1994. Seed dispersal in a marine macrophyte: implications for colonization and restoration. Ecology 75 , 1927-1939

Póvoa dos Reis, M., 1973. Curso de Iniciação à Investigação Cientifĩca. Ria de Aveiro II. Instituto D. Ernesto Sera de Oliveira, Coimbra, 53 pp.

Pasqualini, V., Pergent-Martini, C., Fernandez, C., Ferrat, L., Tomaszewski, J.E., Pergent, G., 2006. Wetland monitoring: aquatic plant changes in two Corsican coastal lagoons (Western Mediterranean Sea). Aquat. Conserv. Mar. Freshw. Ecosyst. 16, 43-46

Peñuelas, J., Menéndez, M., 1990. $\mathrm{HCO}_{3}{ }^{-}$as an exogenous carbon source for Ruppia cirrhosa (Petagna) Grande. Arch. Hydrobiol. 120, 89-96.

Pergent, G., Pasqualini, V., Pergent-Martini, C., Ferrat, L., Fernandez, C., 2006. Variability of Ruppia cirrhosa in two coastal lagoons with differing anthropogenic stresses. Bot. Mar. 49, 103-110.

Pettit, J.M., 1984. Aspects of flowering and pollination in marine angiosperms. Oceanogr. Mar. Biol. Ann. Rev. 22, 315-342.

Philbrick, C.T., Les, D.H., 1996. Evolution of aquatic angiosperm reproductive systems. BioScience 46, 813-826.

Philbrick, C.T., 1988. Evolution of underwater outcrossing from aerial pollination systems: a hypothesis. Ann. Missouri Bot. Garden 75, 836-841.

Reese, G., 1962. Zur intragenerischen taxonomie der gattung Ruppia L. ein cytosystematischer beitrag. Z. Bot. 50, 237-264.

Richardson, F.D., 1980. Ecology of Ruppia maritima in New Hampshire (USA) tidal marshes. Rhodora 82, 403-439.

Richardson, F.D., 1983. Variation, Adaptation and Reproductive Biology in Ruppia maritima L. Populations from New Hampshire Coastal and Estuarine Tidal Marshes. University of New Hampshire (Ph.D. Dissertation).
Rodrigues, R.S., Savant, S.B., Jagtap, T.G., 2009. A note on Ruppia species (Ruppiaceae) from abandoned saltpan in the Gulf of Kutch, India. Ind. J. Mar. Sci. 38, 457-460.

Roze, M.E., 1904. Recherches sur les Ruppia. Bull. Soc. Bot. Fr. 41, 466-480.

Sand-Jensen, K., Borum, J., 1991. Interactions among phytoplankton periphyton, and macrophytes in temperate freshwaters and estuaries. Aquat. Bot. 41, $137-175$

Santamaría, L., Hootsmans, J.M., 1998. The effect of temperature on the photosynthesis, growth and reproduction of a Mediterranean submerged macrophyte Ruppia drepanensis. Aquat. Bot. 60, 169-188.

Santamaría, L., 2002. Why are most aquatic plants widely distributed? Dispersal, clonal growth and small-scale heterogeneity in a stressful environment. Acta Oecol. 23, 137-154.

Setchell, W.A., 1946. The genus Ruppia L. Proc. Calif. Acad. Sci. 25, 469-478.

Sfriso, A., Facca, C., 2007. Distribution and production of macrophytes in the lagoon of Venice: comparison of actual and past abundance. Hydrobiologia 577, $71-85$.

Sfriso, A., Marcomini, A., 1996. Decline of Ulva growth in the lagoon of Venice. Bioresour. Technol. 58, 299-307.

Sfriso, A., Favaretto, M., Ceoldo, S., Facca, C., Marcomini, A., 2005. Organic carbon changes in the surface sediments of the Venice Lagoon. Environ. Int. 31, 1002-1010.

Sfriso, A., Facca, C., Ghetti, P.F., 2007. Rapid Quality Index (R-MaQI) based mainly on macrophyte associations, to assess the ecological status of Mediterranean transitional environments. Chem. Ecol. 23, 1-11.

Sfriso, A., Curiel, D., Rismondo, A., 2009a. The Venice lagoon. In: Cecere, E., Petrocelli, A., Izzo, G., Sfriso, A. (Eds.), Flora and Vegetation of the Italian Transitional Water Systems. CoRiLa, Multigraf, Spinea, Venezia, pp. 17-80.

Sfriso, A., Facca, C., Ghetti, P.F., 2009b. Validation of the macrophyte quality index (MaQI) set up to assess the ecological status of Italian marine transitional environments. Hydrobiologia 617, 117-141.

Sfriso, A., 2008. Ruppia maritima L. e Ruppia cirrhosa (Petagna) Grande (Helobiae Spermatophyta) in laguna di Venezia. Lav. Soc. Ven. Sc. Nat. 33, 41-46.

Sfriso, A., 2010. Chlorophyta multicellulari e fanerogame acquatiche. Ambienti di transizione italiani e litorali adiacenti. I Quaderni ARPAEmilia-Romagna. Odoya srl, Bologna, pp. 320.

Shili, A., Ben Maïz, N., Boudouresque, C.F., Trabelsi, E.B., 2007. Abrupt changes in Potamogeton and Ruppia beds in a Mediterranean lagoon. Aquat. Bot. 87, 181-188.

Short, F., Carruthers, T., Dennison, W., Waycott, M., 2007. Global seagrass distribution and diversity: a bioregional model. J. Exp. Mar. Biol. Ecol. 350, $3-20$.

Signorini, A., Massini, G., Migliore, G., Tosoni, M., Marrone, C., Izzo, G., 2008. Sediment biogeochemical differences in two pristine Mediterranean coastal lagoons (in Italy) characterized by different phanerogam dominance - a comparative approach. Aquat. Conserv. Mar. Freshw. Ecosyst. 18, 27-44.

Stebbins, G.L., 1971. Chromosomal Evolution in Higher Plants. Edward Arnold, London.

Stevenson, J.C., 1988. Comparative ecology of submersed grass beds in freshwater estuarine, and marine environments. Limnol. Oceanogr. 33, 867-893.

Stewart, G.R., Lee, J.A., 1974. The role of proline accumulation in halophytes. Planta $120,279-289$.

Strazisar, T., Koch, M.S., Dutra, E., Madden, C.J., 2013. Ruppia maritima L. seed bank viability at the Everglades-Florida Bay ecotone. Aquat. Bot. 111, 26-34.

Talavera, S., García-Murillo, P., Herrera, J., 1993. Chromosome numbers and a new model for karyotype evolution in Ruppia L. (Ruppiaceae). Aquat. Bot. 45, $1-13$.

Tallon, G., 1957. Ruppiacées de Camargue. Terre Vie 11, 103-116.

Teixeira da Silva, E., Asmus, M.L., 2001. A dynamic simulation model of the widgeon grass Ruppia maritima and its epiphytes in the estuary of the Patos Lagoon, RS, Brazil. Ecol. Model. 137, 161-179.

Tomlinson, P.B., 1982. Potamogetonaceae. In: Metcalfe, C.R. (Ed.), Anatomy of the Monocotyledons. VII. Helobiae (Alismatidae). Clarendon Press, Oxford, pp. 270-335.

Triest, L., Sierens, T., 2009a. High diversity of Ruppia meadows in saline ponds and lakes of the western Mediterranean. Hydrobiologia 634, 97-105.

Triest, L., Sierens, T., 2009b. Biogeographical patterns of Ruppia in the Mediterranean: new insights on diversity and dispersal. International Conference on Mediterranean Temporary Ponds (Menorca), 137-148.

Triest, L., Sierens, T., 2010. Chloroplast sequences reveal a diversity gradient in the Mediterranean Ruppia cirrhosa complex. Aquat. Bot. 93, 68-74.

Triest, L., Sierens, T., 2013. Is the genetic structure of Mediterranean Ruppia shaped by bird-mediated dispersal or sea currents? Aquat. Bot. 104, 176-184.

Triest, L., Sierens, T., 2014. Seagrass radiation after messinian salinity crisis reflected by strong genetic structuring and out-of-Africa scenario (Ruppiaceae) PLoS ONE 9 (8), e104264, http://dx.doi.org/10.1371/journal.pone.0104264.

Triest, L., Symoens, J.J., 1991. Isozyme variation in populations of the submerged halophyte Ruppia (Ruppiaceae). In: Triest, L. (Ed.), Isozymes in water plants. Op. Bot. Belg. 4, 117-134.

Triest, L., 1991. Enzyme polymorphism and its relationships to biological features in aquatic plants (including a comparison with terrestrial plants). In: Triest, L. (Ed.), Isozymes in water plants. Op. Bot. Belg. 4, 201-240.

Triest, L., 2008. Molecular ecology and biogeography of mangrove trees towards conceptual insights on gene flow and barriers: a review. Aquat. Bot. 89 138-154.

Van Ooststroom, S.J., Reichgelt, Th.J., 1964. Ruppiaceae. Flora Neerl. 1, 80-83. 
Van Vierssen, W., Van Wijk, R.J., Van Der Zee, J.R., 1981. Some additional notes on the cytotaxonomy of Ruppia taxa in western Europe. Aquat. Bot. 11, 297-301.

Verhoeven, J.T.A., 1975. Ruppia communities in the Camargue, France. Distribution and structure, in relation to salinity and salinity fluctuations. Aquat. Bot. 1 , 217-242.

Verhoeven, J.T.A., 1979. The ecology of Ruppia-dominated communities in western Europe. I. Distribution of Ruppia representatives in relation to their autecology. Aquat. Bot. 6, 197-268.

Verhoeven, J.T.A., 1980. The ecology of Ruppia-dominated communities in western Europe. III. Aspects of production, consumption and decomposition. Aquat. Bot. 8, 209-253.

Viaroli, P., Bartoli, M., Bondavalli, C., Christian, R.R., Giordani, G., Naldi, M., 1996. Macrophyte communities and their impact on benthic fluxes of oxygen, sulphide and nutrients in shallow eutrophic environments. Hydrobiologia 329 105-119.

Vromans, D.C., Adams, J.B., Riddin, T., 2013. The phenology of Ruppia cirrhosa (Petagna) Grande and Chara sp. in a small temporarily open/closed estuary, South Africa. Aquat. Bot. 110, 1-5.

Wetzel, R.G., 1975. Limnology. Saunders, Philadelphia.

Williams, S.L., Orth, R.J., 1998. Genetic diversity and structure of natural and transplanted eelgrass populations in the Chesapeake and Chincoteague Bays. Estuaries 21, 118-128.

Zhao, L.C., Wu, Z.Y., 2008. A review on the taxonomy and evolution of Ruppia. J. Syst. Evol. 46, 467-478. 